\title{
Complete Urethral Rupture Related with Penile Fracture Occurring during Sexual Intercourse: A Case Report and Review of the Literature
}

\author{
Cinsel Illişki Nedeniyle Oluşmuş Penil Fraktür ile Illişkili Tam Üretral Rüptür: Olgu Sunumu ve \\ Literatür Taraması
}

\author{
(D) Reha Girgin \\ Bulent Ecevit University Faculty of Medicine, Department of Urology, Zonguldak, Turkiye
}

\begin{abstract}
Complete disruption of the urethra due to penile fracture is a very rare occurrence. Herein, we report a case of a 39-year-old man who presented with penile fracture and complete disruption of the urethra as a result of sexual intercourse and present a review of the literature on penile fracture. Surgical exploration at presentation was performed and primary repair was done. In follow-up, the patient reported moderate erectile dysfunction which over time responded to phosphodiesterase- 5 inhibitor drugs. Early surgical repair and evaluation for concomitant urethral injury in case of penile fracture is highlighted in this report.
\end{abstract}

Keywords: Penile fracture, Complete urethral rupture, Erectile dysfunction

Öz

Penil fraktür nedeniyle üretranın tam kopması nadiren görülür. Burada, cinsel ilişki sonucu üretra tam kopma ile beraber penil fraktür ile başvuran 39 yaşındaki bir erkek olguyu literatür eşliğinde sunuyoruz. İlk başvuruda hastaya cerrahi eksplorasyon yapıldı ve primer onarım uygulandı. Takipte, hasta fosfodiesteraz-5 inhibitör ilaçlarına cevap veren modarete erektil disfonksiyon bildirdi. Bu olguda, penil fraktür durumunda eşlik eden üretral hasarın değerlendirilmesi ve erken cerrahi onarım vurgulanmıştır.

Anahtar Kelimeler: Penil fraktür, Tam üretra yırtılması, Erektil disfonksiyon

\section{Introduction}

Penile fracture is characterized by tear in the tunica albuginea of any degree resulting from the abrupt bending of the erect penis (1). It may be accompanied by urethral trauma, which can be partial or complete, in up to $38 \%$ of cases (1). Penile fracture can cause some physiological and psychological consequences when therapeutic management is inadequate. On the other hand, with right diagnosis and sufficient surgical management outcomes remain excellent and complications are minimal. Our objective was to present a patient with penile fracture associated with complete urethral rupture due to sexual trauma in light of the literature.

\section{Case Report}

A 39-year-old Turkish man presented to the emergency department 3 hour after blunt trauma to the penis as a result of sexual intercourse. The patient reported a cracking sound and severe penile pain followed by immediate detumescence after striking his erect penis against his partner's perineum. He could not void at presentation though he did not describe blood at the urethral meatus. Physical examination revealed swelling and subcutaneous hematoma throughout the penis and the scrotum. He also had a dorsal-right deviation of the penis. The typical "rolling sign" was present in the right side of the penile shaft. There were painless scrotal swelling and palpable testicles on scrotal examination. Abdominal

Correspondence: Reha Girgin MD, Bulent Ecevit University Faculty of Medicine, Department of Urology, Zonguldak, Turkiye

Phone: +90 5378865912 E-mail: mujdereha@hotmail.com ORCID-ID: orcid.org/0000-0003-1132-8629

Received: $12.03 .2017 \quad$ Accepted: 13.04.2017

Cite this article as: Girgin R. Complete Urethral Rupture Related with Penile Fracture Occurring during Sexual Intercourse: A Case Report and Review of the Literature. J Urol Surg 2018;5(2):112-115.

${ }^{\circ}$ Copyright 2018 by the Association of Urological Surgery / Journal of Urological Surgery published by Galenos Publishing House. 
examinations showed swelling of the lower abdomen due to inability to void. Urethral catheterization could not be made despite gently insertion. Hematoma in the ventral penile shaft with a rupture of the tunica albuginea of the left cavernosal body and subcutaneous edema was revealed by penile ultrasound. Finding of blood at the urethral meatus suggested a urethral injury which was also demonstrated by urethrography (Figure 1). We informed the patient about the potential complications and took his written consent then he underwent immediate emergency surgery. Under spinal anesthesia, when degloving of the penile skin and evacuation of hematoma was done, partial disruption of both cavernosal bodies and complete urethral disruption were identified (Figure 2). Cavernosal defects were repaired by 3-0 polydioxanone (PDS) suture and a tension-free end-to-end anastomosis of the urethra was performed with 5-0 PDS sutures over an 18 Ch urethral catheter (Figure 2). As prophylaxis, ceftriaxone $1 \mathrm{~g}$ was given until discharge. On the second day following surgical intervention, the patient was discharged with urethral catheter. Foley catheter was not withdrawn for 1 week. Four months later, the patient reported normal voiding function and moderate erectile dysfunction; on physical examination, a little scar tissue was palpable on the dorsal side of the penis shaft. Six months later, the patient was evaluated with uroflowmetry and validated questionnaires. The maximum flow rate was $22 \mathrm{~mL} / \mathrm{s}$ and international prostate symptoms score was 3 , quality of life score was 0 , and international index of erectile function-5 score was 10 . A phosphodiesterase- 5 (PDE-5) inhibitor was started on demand. In the $8^{\text {th }}$ month of follow-up, penile magnetic resonance imaging was performed showing a normal penile integrity and a thickening of skinsubcutaneous tissue in the ventral and dorsal sections (Figure 3 ). It was observed that erectile dysfunction was responsive to PDE-5 inhibitors.

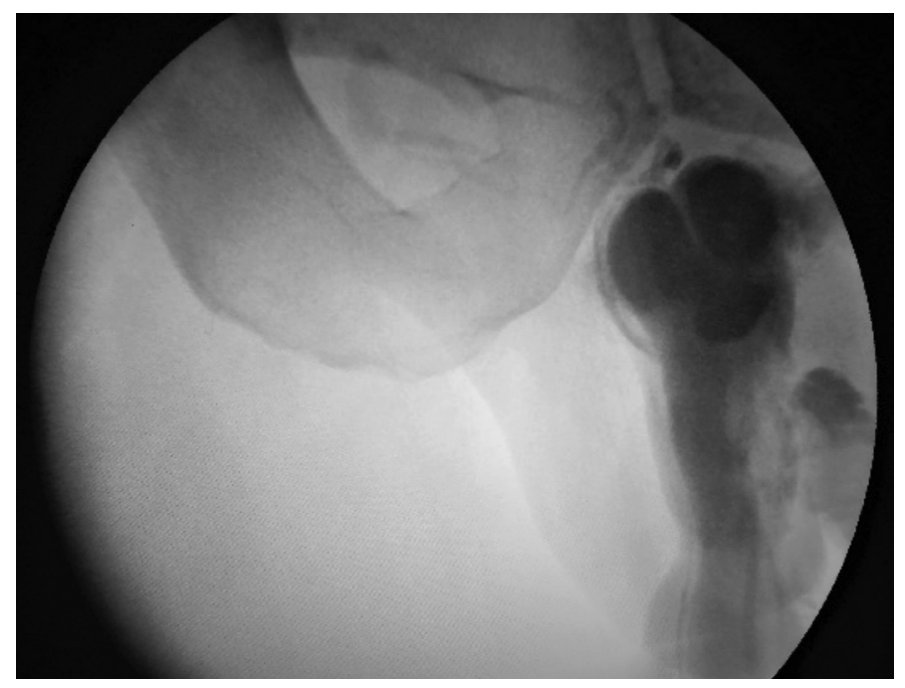

Figure 1. Urethral injury demonstrated by urethrography
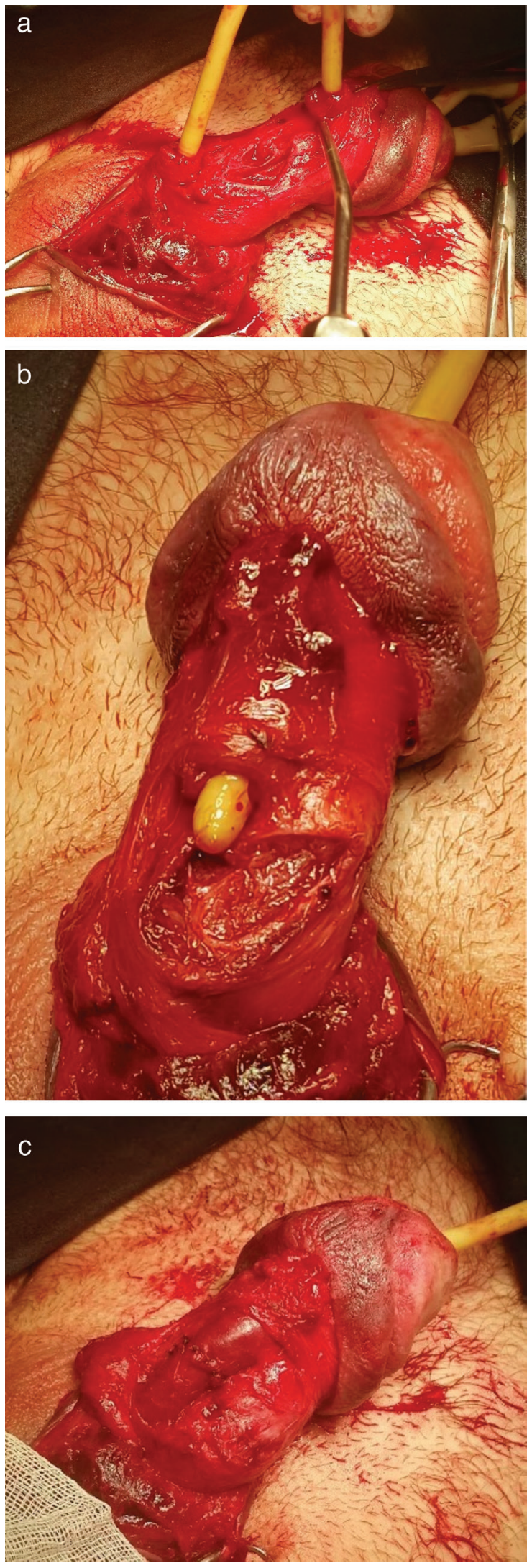

Figure 2. (a) Complete urethral disruption (b) Partial bilateral cavernosal body injury (c) Repaired cavernosal bodies and tensionfree end-to-end anastomosis of the urethra 


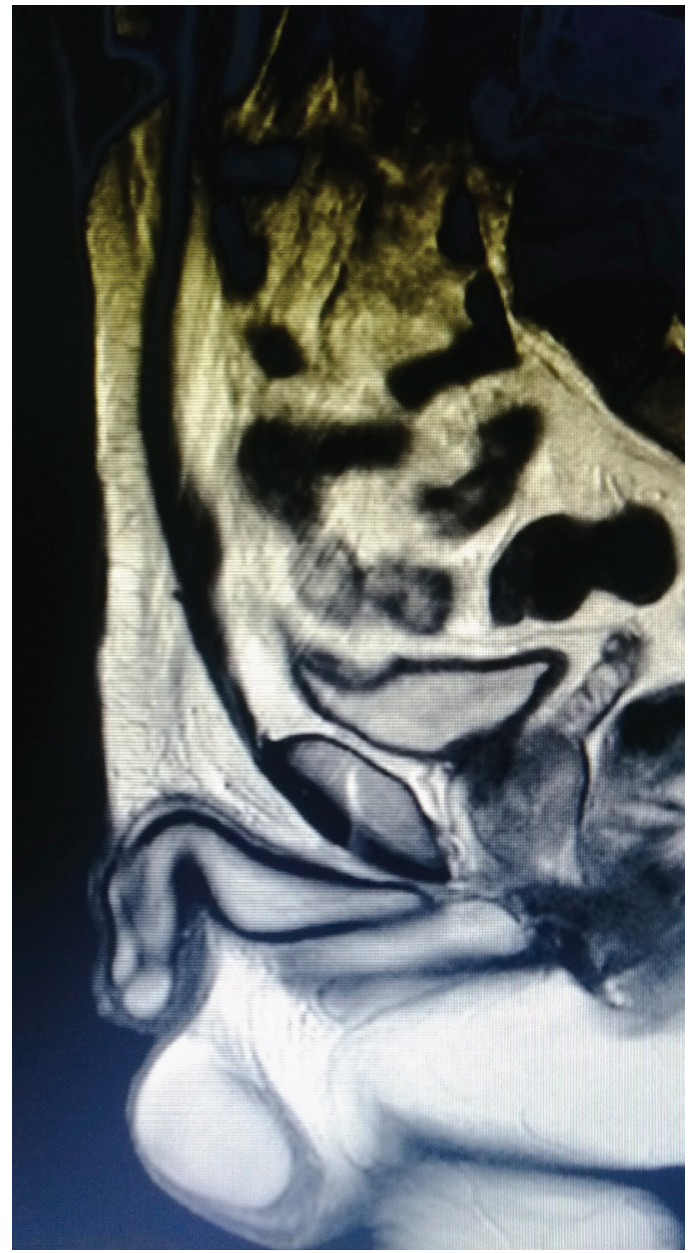

Figure 3. Magnetic resonance imaging of the penis eight months later

\section{Discussion}

Penile fracture is an uncommon situation because of wellpreserved location of the penis and high degree of genital mobility (2). However, during erection, the penis gets rigid and the tunica albuginea gets thinner, predisposing to penile fracture (2). Generally, the laceration is unilateral though bilateral rupture accounts for $2 \%$ to $10 \%$ of cases (3). Penile fracture with urethral injury is a rare situation. Urethral injury should be considered in patients with bilateral corporeal rupture (4). Among the causes of penile fracture, sexual intercourse is at the forefront. Due to this condition which is a cause of highenergy trauma, urethral injury is relatively more common which is generally partial in nature (5). A complete disruption of the urethra is a much less common condition (5). In a series of 312 cases published by Lynch et al. (8), there was also urethral injury in 10 patients. This is the $24^{\text {rd }}$ case of penile fracture with total urethral disruption described in the English literature. There are many studies comparing surgical approach with conservative approach. Shorter duration of hospital stays and improved physiological and functional outcomes, including reduced erectile dysfunction, are associated with immediate operative intervention (6).

In their study including 155 patients with penile fracture, Ibrahiem et al. (9), reported that normal erectile function was observed in $77 \%$ of patients who were treated surgically. Venoocclusive dysfunction, arterial insufficiency, and continuous venous leakage are shown to be the causes of erectile dysfunction after penile fracture (7). Thus, some patients perform sexual acts with extreme fear of recurrence of trauma which may interrupt spontaneity and normality of the act (7). In our case, despite immediate surgical intervention, the patient had moderate erectile dysfunction which responded to PDE-5 inhibitors by time. However, since response to medication was obtained in our patient and there was no need for additional intervention, we did not need further investigation with penile color Doppler ultrasonography.

In about half of the partial anterior urethral disruptions, urethral luminal recanalization will occur (8). Optic urethrotomy or urethral dilatation can treat short strictures. Anastomotic urethroplasty is required in complicated strictures shorter than $1 \mathrm{~cm}$ in length. However, strictures longer than $1 \mathrm{~cm}$ in diameter should be repaired by flap urethroplasty in order to prevent chordee formation. Urethroplasty should be performed at $3^{\text {th }}$ to $6^{\text {th }}$ months in almost all complete disruptions of the anterior urethra in which urethral injury associated with penile fracture is an exception.

A subcoronal or circumferential incision is the best described surgical approach, thus the surgeon can explore all the corporeal bodies and repair if injured (9). Therefore, in our case, we did circumferential incision and repaired all the corporeal defects at the same time. In cases of complete urethral injury, urethral catheter was maintained until 2-3 weeks after the surgical operation $(10,5)$. In our case, the urethral catheter was withdrawn on the $7^{\text {th }}$ postoperative day and no voiding problem developed. Nevertheless, further case studies are needed for more information. In conclusion, this case supports the available data that early surgical intervention reduces the risk of complications.

\section{Ethics}

Informed Consent: Informed consent form was taken from the patient.

Peer-review: Internally peer-reviewed.

Conflict of Interest: No conflict of interest was declared by the author.

Financial Disclosure: The author declared that this study received no financial support. 


\section{References}

1. Boncher NA, Vricella GJ, Jankowski JT, Ponsky LE, Cherullo EE. Penile fracture with associated urethral rupture. Case Report Med 2010;2010:791948.

2. Fergany AF, Angermeier KW, Montague DK. Review of Cleveland Clinic experience with penile fracture. Urology 1999;54:352-355.

3. Tahmaz L, Kilciler M, Gökalp A, Soydan H, Dayanç M, Peker AF. Penis fraktürlü 14 olguda cerrahi tedavi sonuçlarımız. Türk Üroloji Dergisi 2000;26:310312.

4. Karadeniz $T$, Topsakal $M$, Ariman $A$, Erton $H$, Basak D. Penil fracture: Differential diagnosis, management and outcome. Br J Urol 1996;77:279281.

5. Koifman L, Cavalcanti AG, Manes CH, Filho DR, Favorito LA. Penile fractureExperience in 56 cases. Int Braz J Urol 2003;29:35-39.
6. Kowalczyk J, Athens A, Grimaldi A. Penile fracture: an unusual presentation with lacerations of bilateral corpora cavernosa and partial disruption of the urethra. Urol 1994;44:599-600.

7. El-Assmy A, El-Tholoth HS, Abou-El-Ghar ME, Mohsen T, Ibrahiem EH. Risk factors of erectile dysfunction and penile vascular changes after surgical repair of penile fracture. Int J Impot Res 2012;24:20-25. Epub 2011 Aug 11.

8. Lynch D, Martinez-Piñeiro L, Plas E, Serafetinidis E, Turkeri L, Santucci R, Hohenfellner M. Anterior urethral injuries. EAU Guidelines on Urological Trauma 2008;4:44-54.

9. Ibrahiem el-HI, el-Tholoth HS, Mohsen T, Hekal IA, el-Assmy A. Penile fracture: long-term outcome of immediate surgical intervention. Urology 2010;75:108-111.

10. Soylu A, Yilmaz U, Davarci M, Baydinc C. Bilateral disruption of corpus cavernosum with complete urethral rupture. Int J Urol 2004;11:811-812. 